\title{
Shoulder pain in smokers could be a life changer
}

\author{
Ahmed Sayeed, Fayez Mobarak Mohammed Alshamrani, Abdullah Yahya Amrayn, \\ Abrar Alharbi
}

Department of Internal Medicine, King Abdullah Medical City, Mecca, Saudi Arabia

\section{Correspondence to}

Dr Ahmed Sayeed, sayeedheena@gmail.com sayeedmodi@yahoo.co.in

Accepted 20 May 2017

\section{CASE HISTORY}

A 51-year-old Saudi man presented to us with a 4-week history of right shoulder and chest pain radiating to the back. He also had distal and proximal muscle weakness of the right upper limb.

$\mathrm{He}$ is a chronic smoker for 40 years, about three packs per day. His lifetime exposure to tobacco was 120 pack years. He lost about $3 \mathrm{~kg}$ in the last 1 week. There was no history of cough or shortness of breath or fever with night sweats.

He had a history of pulmonary tuberculosis 28 years ago and taken complete treatment for 1 year.

On examination, there was ptosis, enophthalmos, narrowing of palpebral fissure and miosis of the right eye and anhidrosis of the right half of the face (figure 1). He also had clubbing of fingers.

The motor system examination of the right upper limb showed grade 3 plus power and weak handgrip.

The chest examination showed decreased movement with impaired note and reduced intensity of breath sounds on the right upper half of the chest.

The chest X-ray showed a right apical lobe mass with clear evidence of volume loss on right lung and this finding was confirmed on CT chest, which also showed a right apical lobe mass (figure 2).

He underwent bronchoscopy with broncheoalveolar lavage, which showed squamous cell carcinoma.

A diagnosis of a Pancoast tumour caused by a right apical mass due to squamous cell carcinoma was made.

He has undergone staging CT scan and is being planned for chemotherapy.

\section{DISCUSSION}

Pancoast tumour is defined as a tumour which invades any structures of the apex of the chest like first rib, brachial plexus, sympathetic chain and stellate ganglion near the apex of the lung.

The aetiology is based on the site of lesion and is divided into central, preganglionic and postganglionic. The central causes are stroke, tumour and

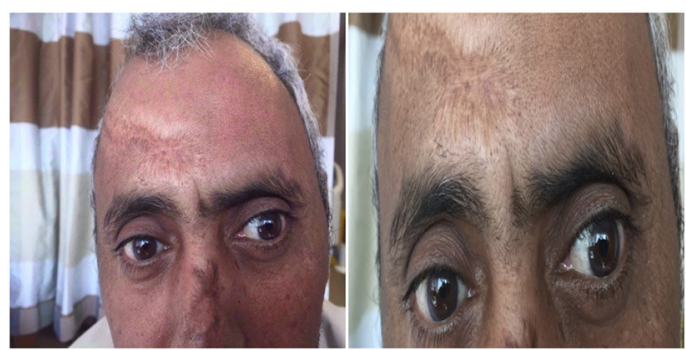

Figure 1 Ptosis and miosis in the right eye.

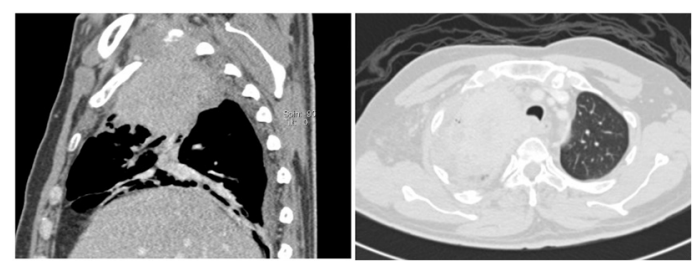

Figure 2 Mass in the right apical lobe.

Learning points

Shoulder pain in smokers could be a symptom of Pancoast tumour.

- Chemotherapy with radiotherapy followed by surgery is the treatment of choice for Pancoast tumour.

demyelination. The preganglionic causes are subclavian artery aneurysm, Pancoast tumour and iatrogenic trauma. The postganglionic causes include trauma, iatrogenic neck dissection and tumours. ${ }^{2}$

The Pancoast tumour usually presents with shoulder pain due to invasion of the brachial plexus or parietal pleura. The diagnosis is usually obtained by ultrasound or CT-guided core biopsy of the apical tumour.

The treatment depends on the stage of the disease. The induction chemotherapy followed by surgery results in better survival rate. The surgery is undertaken after 5 weeks of chemotherapy and it involves enbloc resection of the tumour and the chest wall along with other involved structures like sympathetic ganglion, stellate ganglion and so on. ${ }^{3}$

Contributors AS: reviewed the case history, designed the case report and wrote the discussion. FMMA: reviewed the history and assisted in designing the case report. AYA and AJA: reviewed the literature and contributed to discussion.

Competing interests None declared.

Patient consent Obtained.

Provenance and peer review Not commissioned; externally peer reviewed.

(c) BMJ Publishing Group Ltd (unless otherwise stated in the text of the article) 2017. All rights reserved. No commercial use is permitted unless otherwise expressly granted.

\section{REFERENCE}

1 Shen KR, Meyers BF, Larner JM, et al. Special treatment issues in lung cancer: accp evidence-based clinical practice guidelines (2nd edition). Chest 2007;132:290S-305.

2 Maloney WF, Younge BR, Moyer NJ. Evaluation of the causes and accuracy of pharmacologic localization in Horner's syndrome. Am J Ophthalmol 1980;90:394-402.

3 Buderi SI, Shackcloth M, Woolley S. Does induction chemoradiotherapy increase survival in patients with pancoast tumour? Interact Cardiovasc Thorac Surg 2016;23:821-5. 
Copyright 2017 BMJ Publishing Group. All rights reserved. For permission to reuse any of this content visit http://group.bmj.com/group/rights-licensing/permissions.

BMJ Case Report Fellows may re-use this article for personal use and teaching without any further permission.

Become a Fellow of BMJ Case Reports today and you can:

- Submit as many cases as you like

- Enjoy fast sympathetic peer review and rapid publication of accepted articles

Access all the published articles

- Re-use any of the published material for personal use and teaching without further permission

For information on Institutional Fellowships contact consortiasales@bmjgroup.com

Visit casereports.bmj.com for more articles like this and to become a Fellow 